FisiPublik : Jurnal IImu Sosial dan Politik

https://journal.uwgm.ac.id/index.php/fisipublik

P-ISSN: 2528-2689; E-ISSN: 2540-9751

Vol 04 No 02 November 2019,

\title{
Analisis Minat Remaja dalam Berorganisasi di Kelurahan Lempake Kota Samarinda
}

\author{
Dina Akmila1 ${ }^{1}$, Said Zulkifli², M. Husni³ ${ }^{3}$, Shorea Helminasari ${ }^{4}$ \\ ${ }^{1234}$ Program Studi Ilmu Administrasi Negara, Fakultas Ilmu Sosial dan Ilmu Politik \\ Universitas Widya Gama Mahakam Samarinda
}

Email: dinaaaakmila@gmail.com, saidzulkifli58@gmail.com, husni@uwgm.ac.id, shorea@uwgm.ac.id

\begin{abstract}
Abstrak
Tujuan penulisan skripsi ini adalah untuk mengetahui bagaimana minat serta faktor pendukung dan faktor penghambat remaja di Kelurahan Lempake. Fokus penelitian ini meneliti bagaimana minat remaja berdasar dari tiga faktor yaitu faktor dorongan dari dalam diri, faktor motivasi sosial, dan faktor emosional. Jenis penelitian ini yaitu penelitian kualitatif, dimana teknik analisisnya menggunakan analisis data model interaktif. Dari hasil analisis data diketahui bahwa minat remaja didasari dari faktor dorongan dari dalam diri, faktor motivasi sosial, dan faktor emosional. Akan tetapi dari tiga faktor tersebut yang sangat berperan ialah faktor motivasi sosial. Faktor pendukung remaja dalam berorganisasi selain yaitu lingkungan tempat tinggal, keluarga, dan teman, sedangkan untuk faktor yang menghambat minat tidak ada akan tetapi terkadang faktor yang menghambat remaja untuk mengikuti kegiatan organisasi yaitu waktu kuliah yang berbenturan dengan kegiatan organisasi.
\end{abstract}

Kata kunci: Minat, Remaja, Organisasi. 
FisiPublik : Jurnal IImu Sosial dan Politik

https://iournal.uwgm.ac.id/index.php/fisipublik

P-ISSN: 2528-2689; E-ISSN: 2540-9751

Vol 04 No 02 November 2019,

\title{
Interest analysis in a youth organization in lempake District, City of Samarinda
}

\begin{abstract}
Abstrak
The purpose of writing this is to see how interest and supporting factors and the barrier teenager in Lempake District. The focus of this study examines how the interest of young people based on three factors, Encouragement from, that is, social motivation factor, emotional and factors. The kind of research this is the qualitative research was conducted, where the analysis technique using analysis data interactive model, But of the three factors in who was instrumental is motivation. social factors Contributing factors to organize a teenager in but that is their neighborhoods, the family, and a friend, as for factor that impedes interest there is no but sometimes factors that hamper young people to join the organization which is in college conflicts with the organization.
\end{abstract}

Keywords: Interest, Teenagers, Organization. 
FisiPublik : Jurnal IImu Sosial dan Politik

https://journal.uwgm.ac.id/index.php/fisipublik

P-ISSN: 2528-2689; E-ISSN: 2540-9751

Vol 04 No 02 November 2019,

\section{Pendahuluan}

Indonesia merupakan negara kesatuan yang memiliki banyak organisasi, baik itu organisasi formal maupun informal. Keanggotaan organisasi tidak memandang umur, suku, gender, maupun agama. Semua warga negara Indonesia berhak mengikuti organisasi yang ada selama organisasi tersebut tidak melanggar hukum yang belaku. Organisasi merupakan sekumpulan orang yang bekerjasama untuk mencapai tujuan tertentu. Pembentukan organisasi dilakukan secara sukarela berdasarkan kesamaan aspirasi, kehendak, kebutuhan, kepentingan, kegiatan dan tujuan. Keanggotaan suatu organisasi sering kali didominasi oleh kelompok usia dewasa. Akan tetapi saat ini banyak juga kelompok usia remaja yang turut bergabung dalam sebuah organisasi.

Masa remaja merupakan masa transisi dari masa kanak-kanak menuju masa dewasa, kisaran umur dari 10 hingga 24 tahun. Di masa inilah seseorang mencari jati diri untuk membentuk karakter kepribadian, seperti pengalaman baru maupun teman baru. Pada masa remaja, organisasi yang terbentuk seringkali berada di lingkungan sekolah atau lingkungan tempat tinggal. Penting bagi remaja untuk menumbuhkan minatnya dalam berorganisasi karena wawasan baru dapat diperoleh oleh remaja dari berorganisasi. Hal ini dikarenakan adanya interaksi yang muncul antar anggota organisasi dalam bentuk diskusi sehingga dapat bertukar pikiran. Interaksi inilah yang akan memberikan wawasan baru bagi remaja. Selain itu, dalam berorganisasi banyak program kerja yang dapat dilakukan untuk mengembangkan potensi remaja agar menjadi lebih kreatif, disiplin, toleransi, menumbuhkan rasa solidaritas, dan beradaptasi dengan lingkungan.

Berdasarkan situs resmi kelurahan lempake menurut data BPS tahun 2016 memiliki luas wilayah $32,83 \mathrm{~km}^{2}$ dan memiliki 48 RT dengan jumlah penduduk 16.363 jiwa (samarindakota.bps.go.id). Dari pengamatan dan pengalaman penulis di kelurahan ini cukup banyak remajanya. Dalam mengadakan kegiatan para remaja ini juga mau untuk berpartisipasi membantu jalannya kegiatan, salah satunya seperti perlombaan dalam perayaan Hari Ulang Tahun Republik Indonesia maupun perayaan Hari Ulang Tahun Kelurahan Lempake yang dirayakan pada bulan Agustus 2017 lalu.

Remaja-remaja sangat antusias ikut berpartisipasi dalam membantu jalannya kegiatan. Secara tidak langsung keikutsetaan remaja tersebut memperlihatkan bahwa mereka memiliki minat untuk bergabung dan membantu berbagai kegiatan yang ada di lingkungan tempat tinggal mereka. Minat ini pula lah yang mendorong remaja untuk bergabung dalam berbagai 
FisiPublik : Jurnal IImu Sosial dan Politik

https://journal.uwgm.ac.id/index.php/fisipublik

P-ISSN: 2528-2689; E-ISSN: 2540-9751

Vol 04 No 02 November 2019,

organisasi yang ada di lingkungan Kelurahan Lempake seperti Taruna Siaga Bencana (TAGANA), Kampung Siaga Bencana (KSB), Ikatan Remaja Masjid (IRMA) dan Pusat Informasi dan Konseling Remaja (PIK-R). Berdasarkan hal tersebut, maka peneliti tertarik mengambil judul "Analisis Minat Remaja Dalam Berorganisasi di Kelurahan Lempake Kota Samarinda"

\section{Metode Penelitian}

Jenis penelitian Kualitatif, menggunakan key informan dan informan dalam penelitian ini meliputi : Lurah Lempake, sedangkan informan yaitu remaja kelurahan Lempake. Pengumpulan data dilakukan dengan penelitian kepustakaan dan penelitian lapangan (observasi, dokumentasi, wawancara). Analisis selama di lapangan model Miles and Huberman. Aktivitas dalam analisis data, yaitu data collection, data reduction, data display, dan conclusion drawing/verification. Selanjutnya model interaktif dalam analisis data:

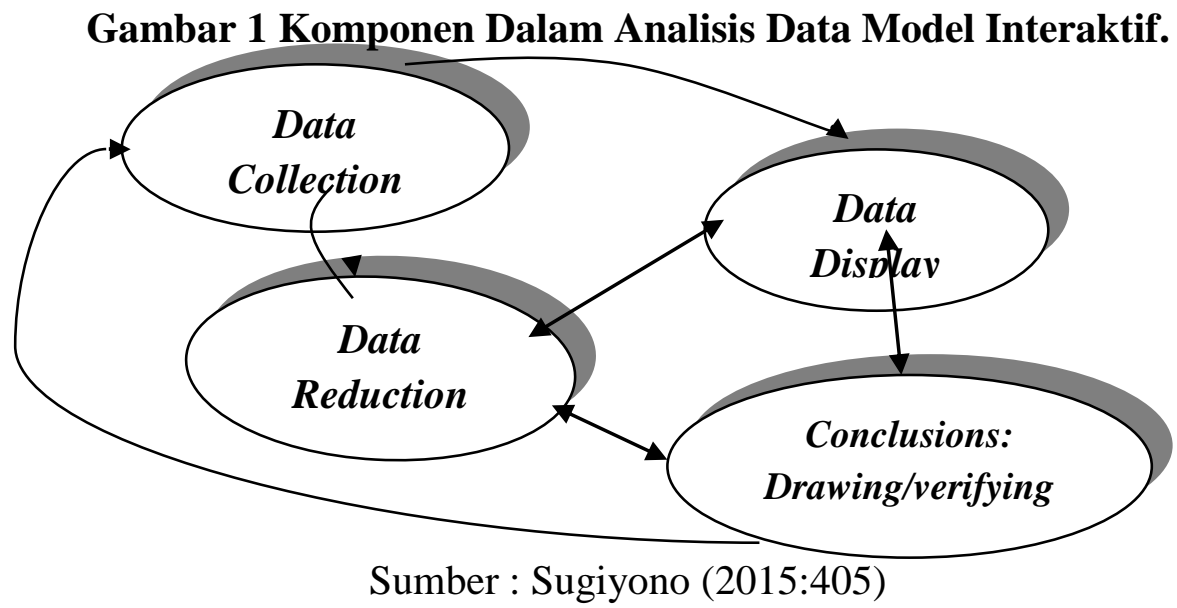

\section{Pembahasan}

\section{Faktor Dorongan Dari dalam Diri}

Faktor dorongan dari dalam diri diartikan sebagai ketertarikan yang timbul dari dalam diri individu itu sendiri. Berdasarkan hasil penelitian bahwa semua informan memiliki dorongan dari dalam diri untuk bergabung dalam sebuah organisasi. Akan tetapi dorongan dari dalam diri tersebut memiliki tujuan yang berbeda-beda. Dorongan tersebut dapat dilihat dari informan yang mengikuti organisasi itu karena ingin menolong orang lain, bisa dikatakan rasa empati dan tanggung jawab yang ada didalam diri informan tersebut sangat tinggi, sehingga mereka terdorong untuk membantu sesama. Selain itu ada juga informan yang ingin 
FisiPublik : Jurnal IImu Sosial dan Politik

https://journal.uwgm.ac.id/index.php/fisipublik

P-ISSN: 2528-2689; E-ISSN: 2540-9751

Vol 04 No 02 November 2019,

menambah pengalaman, menambah teman, dan melatih public speakingnya, itu lebih kepada aktualisasi diri informan itu sendiri. Informan yang mengikuti organisasi juga terdorong karena mereka memiliki tujuan yang berbeda-beda yang hendak dicapai sesuai dengan kompetensinya masing-masing. Seperti yang kuliah dijurusan kesehatan mereka menyalurkan kemampuannya pada organisasi PIK-Remaja, informan yang rasa empatinya tinggi menyalurkan kemampuannya di organisasi KSB. Walaupun hampir semua informan mengikuti lebih dari satu organisasi, akan tetapi salah satu dari organisasi tersebut ada yang benar-benar menyalurkan kemampuan mereka.

\section{Faktor Motivasi Sosial}

Faktor motivasi sosial dapat diartikan sebagai faktor untuk melakukan suatu aktifitas atau kegiatan agar dapat diterima dan diakui oleh lingkungannya. Faktor motivasi sosial sosial yang mempengaruhi informan untuk bergabung dalam organisasi yaitu lingkungan tempat tinggal, keluarga, dan teman yang mendukung adanya organisasi. Dapat dikatakan demikian karena di lingkungan tempat tinggal para informan sangat mendukung adanya organisasi seperti disediakannya sarana prasarana seperti tempat berkumpul atau posko, selain itu keluarga informan yaitu orang tua mereka sendiri juga ikut mendorong untuk bergabung diorganisasi bahkan keluarga dari informan tersebut ada yang ikut bergabung juga didalam organisasi seperti orang tua, adik, dan kakak dari informan, begitu pula dengan teman-teman informan itu sendiri.

Lingkungan tempat tinggal yang mendukung bisa dilihat dari bagaimana lingkungan tersebut memfasilitasi organisasi yang berada disana seperti organisasi KSB yang disediakan posko, perahu, tandu, serta alat lainnya yang mendukung kegiatan organisasi sesuai dengan program kerjanya KSB yaitu membantu apabila terjadi bencana. Bencana yang sering terjadi di Kelurahan Lempake yaitu tanah longsor dan banjir, pada saat terjadi bencana itulah anggota organisasi Tagana dan KSB turut membantu. Kemudian organisasi IRMA, sesuai dengan nama organisasinya fasilitas yang digunakan yaitu Masjid. Setiap hari besar Islam, organisasi IRMA tidak pernah ketinggalan untuk membuat acara ataupun kegiatan untuk memperingati hari besar Islam tersebut. Untuk organisasi PIK-R sendiri, karena organisasi ini baru dibentuk kurang lebih 6 bulan yang lalu tepatnya pada bulan Agustus 2017, sejauh ini kegiatannya hanya sosialisasi saja. Selain posko dan Masjid, masyarakatnya juga bersedia 
FisiPublik : Jurnal IImu Sosial dan Politik

https://journal.uwgm.ac.id/index.php/fisipublik

P-ISSN: 2528-2689; E-ISSN: 2540-9751

Vol 04 No 02 November 2019,

rumahnya dijadikan tempat untuk berkumpul. Untuk anggota organisasi juga memiliki baju khusus untuk yang menunjukan identitasnya sebagai anggota sebuah organisasi.

Dukungan dari keluarga juga mempengaruhi informan untuk bergabung dalam organisasi. Dukungan itu seperti izin bergabung dalam organisasi, memberikan fasilitas seperti trasnportasi, diberi semangat, dan masih banyak lagi. Selain itu juga keluarga yang juga ikut bergabung dalam organisasi itu memberikan dorongan tersendiri bagi anak untuk ikut juga dalam berorganisasi. Sebagian besar informan mengatakan teman juga mempengaruhi informan untuk bergabung dalam organisasi. Mereka berpendapat bahwa adanya teman yang mereka kenal didalam organisasi dalam organisasi akan mempermudah proses adaptasi, sedangkan apabila tidak ada, maka proses adaptasi akan lebih sulit. Akan tetapi ada pula informan yang mengatakan teman tidak mempengaruhi keputusannya untuk bergabung dalam organisasi karena informan tersebut memiliki dorongan dari dalam diri yang memprioritaskan membantu orang orang lain, sehingga tanpa adanya teman ia tetap bergabung dalam organisasi.

\section{Faktor Emosional}

Faktor emosional dapat diartikan sebagai faktor yang menimbulkan perasaan suka atau tidak suka kepada individu dalam melakukan kegiatan. Dari hasil penelitian, adanya faktor emosional timbul karena faktor dorongan dari dalam diri dan faktor motivasi sosial. Semua informan merasakan senang setelah bergabung dalam organisasi. Perasaan senang ini dirasakan setelah bergabung mereka merasakan banyak manfaat yang mereka dapat karena ikut berpartisipasi dalam kegiatan yang dilaksanakan. Akan tetapi ada beberapa informan yang merasakan sedih, selain itu ada juga informan yang merasakan ada sesuatu yang kurang, ada yang merasa iri, bahkan ada yang merasa biasa saja apabila tidak ikut kegiatan dalam organisasi. Perasaan sedih yang dirasakan karena mereka merasa tidak mengikuti kegiatan yang dilaksanakan, sedih itu disebabkan karena mereka tidak dapat menolong orang lain juga melewatkan kesempatan mereka untuk mendapat pengalaman baru. Ada juga yang merasa kurang, merasa iri, itu disebabkan karena mereka melihat anggota yang lain berkegiatan sedangkan mereka tidak. Ada pula yang merasa biasa saja. 
FisiPublik : Jurnal IImu Sosial dan Politik

https://iournal.uwgm.ac.id/index.php/fisipublik

P-ISSN: 2528-2689; E-ISSN: 2540-9751

Vol 04 No 02 November 2019,

\section{Faktor Pendukung}

Faktor pendukung dapat diartikan sebagai faktor yang mendukung remaja dalam berorganisasi di Kelurahan Lempake. Ada berbagai macam faktor yang mendukung yaitu lingkungan tempat tinggal, keluarga, teman, kekompakan para remaja, bahkan ada yang beranggapan bahwa yang paling utama untuk berorganisasi itu dorongan dari dalam diri untuk berorganisasi. Dukungan dari lingkungan tempat tinggal, keluarga, teman sudah dibahas pada pembahasan sebelumnya. Kekompakan yang dimaksud ialah kekompakan para remaja dalam berorganisasi, apabila berkegiatan semua mengusahakan untuk hadir serta membantu. Selain faktor pendukung tersebut, pendukung yang tidak kalah penting yaitu dorongan dari dalam diri untuk berorganisasi. Berbagai macam bentuk faktor mendukung tersebut menjadi motivasi tersendiri bagi para informan.

\section{Faktor Penghambat}

Berdasar hasil wawancara dapat dilihat tidak adanya faktor yang menghambat minat remaja dalam berorganisasi, karena seluruh aspek di lingkungan internal dan eksternalnya mendukung. Adapun hambatan yang muncul yaitu faktor yang menghambat informan untuk mengikuti kegiatan berorganisasi. Ada beberapa hal yang dapat peneliti ambil dari hasil penelitian, diantaranya hampir semua informan mengatakan faktor yang kadang kala menghambat informan untuk mengikuti kegiatan organisasi adalah waktu. Hambatan waktu ini muncul karena semua informan memiliki kesibukan lain diluar organisasi, baik kesibukan sebagai mahasiswa ataupun pekerja. Hal ini mengakibatkan informan tidak selalu dapat mengikuti kegiatan organisasi karena berbenturan dengan jadwal kegiatan utama mereka sebagai mahasiswa atau pekerja. Adanya benturan jadwal ini mengharuskan informan untuk memprioritaskan salah satunya dan sering kali informan lebih mengutamakan kegiatan mereka di dunia perkuliahan atau kerja karena mereka memiliki tanggung jawab yang lebih besar. Sehingga menghambat informan tersebut bergabung dalam kegiatan organisasi. Akan tetapi hambatan tersebut tidak selalu terjadi hanya sesekali.

\section{Kesimpulan}

Minat remaja dalam berorganisasi di Kelurahan Lempake didasari oleh tiga faktor yaitu faktor dorongan dari dalam diri, faktor motivasi sosial, dan faktor emosional. Dapat ditarik kesimpulan dari hasil pembahasan yang telah dipaparkan pada bab sebelumnya faktor yang paling berperan dalam terbentuknya minat remaja dalam berorganisasi yaitu faktor 
FisiPublik : Jurnal IImu Sosial dan Politik

https://journal.uwgm.ac.id/index.php/fisipublik

P-ISSN: 2528-2689; E-ISSN: 2540-9751

Vol 04 No 02 November 2019,

motivasi sosial. Karena didalam faktor motivasi sosial ini banyak dukungan yang diberikan yaitu sarana prasarana dilingkungan tempat tinggal yang mendukung, masyarakat, keluarga, dan teman. Semua informan memiliki faktor dorongan dari dalam diri, akan tetapi apabila faktor motivasi sosialnya tidak mendukung, minat remaja bisa saja tidak tersalurkan. Faktor yang mendukung remaja selain dari sarana prasarana di lingkungan tempat tinggal yang mendukung, masyarakat, keluarga, dan teman. Kekompakan yang telah dibangun remaja pada organisasi itu juga termasuk faktor pendukung, karena suatu organisasi untuk mencapai tujuan harus ada kerja sama yang baik seperti kekompakan para anggota, apabila tidak ada kekompakan maka organisasi tidak akan berjalan dengan baik. Tidak adanya faktor yang menghambat minat remaja dalam berorganisasi, karena seluruh aspek di lingkungan internal dan eksternalnya mendukung.

\section{Daftar Pustaka}

Bagong Suyanto dan Sutinah, (2007), Metode Penelitian Sosial, Penerbit Kencana Prenada Media Group, Jakarta.

Husaini Usman \& Purnomo Setiady Akbar, (2011), Metodologi Penelitian Sosial, Penerbit Bumi Aksara, Jakarta.

Lexy J. Moleong, (2011), Metodologi Penelitian Kualitatif, Penerbit Remaja Rosdakarya, Bandung.

Sugiyono, (2013), Metode Penelitian Pendidikan, Penerbit Alfabeta, Bandung. , (2015), Metode Penelitian Manajemen, Penerbit Alfabeta, Bandung.

Ulber Silalahi, (2012), Metode Penelitian Sosial, Penerbit Refika Aditama, Bandung.

Arti minat https://kbbi.web.id/minat (Diakses 3 Desember 2017, Pukul 23.44)

Data penduduk Kelurahan Lempake https://samarindakota.bps.go.id/Publikasi/view/id/82

(Diakses 3 Desember 2017, Pukul 11.53)

Data penduduk Kota Samarinda https://samarindakota.bps.go.id/linkTabelStatis/view/id/13 (Diakses 3 Desember 2017, Pukul 11.48)

Undang-Undang Kepemudaan http://dispora.sumutprov.go.id/downlot.php?file=15_16-0128-23-49-46_74911_UU_2009_40\%20tentang\%20kepemudaan.pdf $\quad$ (Diakses 13 September 2017, Pukul 10.50) 